\title{
Küresel Ekonomik Kriz Döneminde Türkiye'de Uygulanan Vergi Politikalarının Değerlendirilmesi*
}

\section{Evaluation of Tax Policies Applied in Turkey in the Global Economic Crisis Period}

\author{
Çağlayan Tabar ${ }^{1}$
}

Mircan Tokatlıoğlu²

\section{ARTICLE INFO \\ Submitted : 11.12 .2017 \\ Revised : 22.03.2018 \\ Accepted : 24.04.2018 \\ Available : 30.07 .2018 \\ JEL classification: \\ $\mathrm{H} 2 \mathrm{O}, \mathrm{H} 30$}

Keywords:

Global Economic

Crisis, Tax Policy,

Tax Reduction

\begin{abstract}
A B S T R A C T
An economic crisis is the occurrence of incidents suddenly and unexpectedly in an economy which affects the economy in a negative way. Various policies are implemented to reduce the negative effects of economic crises. Tax policies are one of the these policies. The financial crisis, which occurred in the USA in 2008, grew apace by way of securities and obtained global qualification. The crisis has spread in Turkey through foreign trade, credit and confidence rather than financial instruments. It has come to exist as reel crisis and it has led to disrupt of economic indicators. Initially, monetary policy measures have been taken against the crisis. However, the measures have not been adequate to decrease adverse effects of the crisis. Therefore, fiscal policies, mainly tax policies, have been appealed to. The tax policies implemented in this period were implemented as Value Added Tax and Special Consumption Tax reductions for the sectors most affected by the crisis. The purpose of this study is to evaluate the results of reduction.
\end{abstract}

* Bu makale, Çağlayan Tabar tarafından hazırlanan ve danışmanlığını Prof. Dr. Mircan Tokatlıoğlu'nun yaptığı; 2015 yılında Uludağ Üniversitesi Sosyal Bilimler Enstitüsü’nde “Küresel Ekonomik Krizde Vergi Politikası Önlemleri: Türkiye Örneği” başlığıyla kabul edilen yüksek lisans tezinden üretilmiştir.

${ }^{1}$ Res. Assist. (https://orcid.org/0000-0003-4389-7658), Bursa Uludağ University, Faculty of Economics and Administrative Sciences, Department of Public Finance, Turkey, ctabar@uludag.edu.tr

2 Prof. Dr. (https://orcid.org/0000-0001-6358-9498), Bursa Uludağ University, Faculty of Economics and Administrative Sciences, Department of Public Finance, Turkey, miryildiz@uludag.edu.tr 
Tabar Ç. \& M. Tokatlıoğlu (2018). “Küresel Ekonomik Kriz Döneminde Türkiye'de Uygulanan Vergi Politikalarının Değerlendirilmesi", International Journal of Public Finance, Vol.3, No.1, pp. 27-46.

\section{MAKALE BíLGisi}

Gönderme: 11.12.2017

Düzeltme : 22.03.2018

Kabul : :24.04.2018

Yayın : : 30.07.2018

JEL Kodu:

$\mathrm{H} 2 \mathrm{O}, \mathrm{H} 30$

Anahtar Kelimeler:

Küresel Ekonomik Kriz, Vergi Politikası, Vergi Indirimleri

\begin{abstract}
Ö Z E T
Ekonomik kriz, bir ekonomide aniden ve beklenmedik bir şekilde ortaya çıkan olayların ekonomiyi olumsuz etkilemesidir. Ekonomik krizlerin olumsuz etkilerinin azaltılması için çeşitli politikalar uygulanmaktadır. Bu politikalardan biri de vergi politikasıdır. 2008 yılında Amerika Birleşik Devletleri (ABD)'nde ortaya çıkan finansal kriz, menkul kıymetler aracılığıyla yayılmış ve küresel bir nitelik kazanmıştır. Kriz Türkiye'ye finansal araçlardan ziyade dış ticaret, kredi ve güven kanalıyla bulaşmış, Türkiye'de reel kriz olarak ortaya çıkmış ve ekonomik göstergelerin bozulmasına yol açmıştır. Krize karşı ilk olarak para politikası tedbirleri alınmış fakat bu tedbirler yeterli olmayınca ağırlıklı olarak vergi politikası olmak üzere maliye politikalarına başvurulmuştur. Bu dönemde uygulanan vergi politikaları krizden en çok etkilenen sektörlere yönelik katma değer vergisi ve özel tüketim vergisi indirimleri şeklinde uygulanmıştır. Bu çalışmanın amacı söz konusu indirimlerin sonuçlarını değerlendirmektir.
\end{abstract}

\section{Giriş}

Ekonomik krizlerin önlenmesi ya da atlatılması için hangi politikaların uygulanması gerektiği son yıllarda sıkça gündeme gelen konulardan biridir. Bu bağlamda vergi politikası, krizlerin önlenmesi ya da atlatılması için önerilen politikalar arasında öne çıkmaktadır. Vergi politikası, devletin ekonomiye müdahalesinde başvurduğu maliye politikasının önemli bir aracıdır. Özellikle durgunluk dönemlerinde özel iktisadi faaliyetlerin canlandırılmasında başvurulan vergi indirimleri küresel krizde de karşımıza çıkmıştır.

Ekonomik kriz, 2008 yılında ABD'de emlak kredi piyasasında yaşanan sorunlar nedeniyle ortaya çıkmış, kısa sürede diğer ülke ekonomilerine bulaşarak küresel bir nitelik kazanmış ve dünya ekonomisi durgunluk sürecine girmiştir. Söz konusu krize karşı ilk olarak para politikası önlemleri alınmış fakat istenilen sonuç alınamayınca maliye politikası önlemleri alınmak zorunda kalınmıştır. Bu durum, 1970'li yıllardan sonra benimsenen neo liberal anlayış doğrultusunda etkin olmadığı varsayılan ve dolayısıyla uygulamada gözden düşen maliye politikalarını devletin ekonomiye müdahale aracı olarak tekrar gündeme getirmiştir. Küresel ekonomik krizden tüm dünya ile özellikle de Avrupa Birliği ile ticari ve finansal bağları bulunan Türkiye ekonomisi de etkilenmiştir. Türkiye'de krize karşı alınan önlemler diğer ülkelerdeki önlemlere paralel olarak; önce para politikası daha sonra ise vergi politikasına dayalı maliye politikası önlemleri olmuştur.

Bu çalışma, küresel ekonomik krizin Türkiye ekonomisi üzerindeki olumsuz etkilerini gidermek üzere, uygulanan vergi politikası önlemlerinin sonuçlarını değerlendirme amacını taşımaktadır. Çalışmada önce ekonomik kriz ve vergi politikası arasındaki teorik ilişki ele alınacak, ardından küresel ekonomik krizin Türkiye ekonomisi üzerindeki etkileri incelenecektir. Son olarak ise kriz sürecinde Türkiye'de katma değer vergisi (KDV) ve özel tüketim vergisi (ÖTV) indirimleri, Varlık Barışı uygulaması ve diğer 
Tabar Ç. \& M. Tokatlıoğlu (2018). “Küresel Ekonomik Kriz Döneminde Türkiye'de Uygulanan Vergi

Politikalarının Değerlendirilmesi”, International Journal of Public Finance, Vol.3, No.1, pp. 27-46.

önlemler olarak birkaç şekilde uygulanan vergi politikaları açıklanacak ve sonuçları değerlendirilecektir.

\section{Ekonomik Kriz ve Vergi Politikası}

Ekonomik krizlerde nasıl bir vergi politikası uygulanması gerektiğini açıklamadan önce ekonomik kriz kavramını açıklamak gerekir. Ekonomik krizin tanımı konusunda bir görüş birliği bulunmamaktadır. Özgüven (2001) ekonomik krizi, bir ülkenin dengeli bir durumdan dengesiz bir duruma, istikrarlı bir durumdan istikrarsız bir duruma düşmesi olarak tanımlamaktadır. Daha geniş tanımlamak gerekirse ekonomik kriz; en küçük iktisadi birimden (firma), en büyük iktisadi birime (devlet) doğru iç ve dış borçların, işsizliğin arttığı, fiyatların bazen yükseldiği bazen de düştüğü, üretimin artıp azaldığı ve halkın genellikle siyasi iktidarlara olan güveninin sarsıldığı bir dönemdir.

Oktar ve Dalyancı (2010) ekonomik krizi, iktisadi sistem ya da alt bileşenlerinin işleyişinde beklenmedik bir şekilde ortaya çıkan ve sistemin işleyişini önemli ölçüde olumsuz etkileyen durum olarak tanımlamışlardır. Kibritçioğlu (2001) ise ekonomik krizleri, herhangi bir mal, hizmet üretim faktörü veya döviz piyasasındaki fiyat ve/veya miktarlarda, kabul edilebilir bir değişme sınırının ötesinde gerçekleşen şiddetli dalgalanmalar olarak tanımlamıştır

Krizler genellikle etkiledikleri sektörler dikkate alınarak sınıflandırılırlar. Bu açıdan bakıldığında ekonomik krizler, reel kriz ve finansal kriz olarak ikiye ayrılır. Mal, hizmet ve işgücü piyasalarında yani üretimde ve/veya istihdamda miktar olarak ciddi daralmalar şeklinde ortaya çıkan krizler "reel kriz" olarak ifade edilmektedir. Reel sektör krizleri mal ve hizmet piyasasında kriz ve işgücü piyasasında kriz olmak üzere ikiye ayrılır (Kibritçioğlu, 2001: 174). Mal ve hizmet piyasasındaki krizlerin durgunluk ve enflasyon krizi olmak üzere iki farklı türü bulunmaktadır. Durgunluk krizi; mal ve hizmet piyasalarında toplam arzın toplam talebi normal olarak kabul edilebilen bir seviyenin üzerinde aşmasını ifade etmektedir. Durgunluk krizi içinde bulunan bir ekonomide mal ve hizmetlere yönelik talebin azalması sonucu piyasadaki mallar alıcı bulamamakta ve üretim azalmaktadır. Bu süreçte stoklar artmakta, işletmeler daha düşük kapasite ile çalışmaktadır (Erginay, 2003: 235). Mal ve hizmet piyasalarındaki genel fiyat düzeyinin sürekli artışları enflasyon olarak tanımlanmaktadır. Eğer fiyatlar genel düzeyindeki artışlar belirli bir sınırın üzerindeyse bu durum enflasyon krizi olarak adlandırılır. Reel krizin bir türü olan işsizlik krizi ise, emek piyasalarındaki işsizlik oranlarının normal olarak kabul edilebilecek seviyenin üzerine çıkmasıdır. İşsizlik krizi genellikle durgunluk krizi ile birlikte ortaya çıkmaktadır. Finansal krizler, çeşitli faktörlere bağı olarak finansal piyasalarda ortaya çıkan dalgalanmalar ve buna bağlı olarak finansal piyasaların kendinden beklenilen fonksiyonları yerine getirememesi olarak tanımlanır (Afşar, 2011: 3-4).

Krizler ekonomi üzerinde olumsuz etki yaratmaktadırlar. Ekonomik krizlerin bu olumsuz etkilerinin azaltılması için çeşitli politikalar uygulanmaktadır. Bu politikalardan biri de vergi politikasıdır. Ancak kuramsal yaklaşımların ekonomik sisteme ilişkin bakış 
Tabar Ç. \& M. Tokatlıoğlu (2018). “Küresel Ekonomik Kriz Döneminde Türkiye'de Uygulanan Vergi

Politikalarının Değerlendirilmesi", International Journal of Public Finance, Vol.3, No.1, pp. 27-46.

açıları krizin kavramsallaştırılmasını ve nedenlerini belirlemektedir. Buradan hareketle, kuramsal yaklaşımların sahip oldukları kriz tanımlarına bağlı olarak politika seçenekleri de farklılaşmakta ve vergi politikasının kullanımına ilişkin önerileri değişmektedir.

Liberal yaklaşıma göre "ekonomide tam rekabet koşulları geçerlidir", "faiz oranı, ücret ve fiyatlar esnektir" ve "her arz kendi talebini yaratmaktadır". Bu varsayımlara göre ekonomi daima tam istihdamda bulunacak ve dolayısıyla fiyatlar genel düzeyinde ne yükselme (enflasyon) ne de alçalma (deflasyon) şeklinde önemli dalgalanmalar olmayacaktır. Bu varsayımlar altında ekonomi kaynakları optimum olarak kullanmaktadır. Esnek ücret ve fiyat mekanizması sayesinde tam istihdam kendiliğinden sağlanacak ve ekonomide herhangi bir şok yaşanmayacaktır (Karaçor \& Alptekin \& Gökmenoğlu, 2012: 16). Kısa dönemde bazı dengesizlikler yaşansa bile bu dengesizlikler uzun dönemde kendiliğinden düzelecektir. Bu sebeple liberaller kriz kavramına fazla önem vermezler, verginin sadece mali amacını kabul ederler ve bütçe denkliği ilkesini savunurlar. Bu ilkeye göre bir mali yıl içinde yapılan kamu harcamaları, söz konusu dönem içinde, vergi, resim harç vb. gibi normal gelirlerle karşılanmalı ve bütçe açık veya fazla vermemelidir. Konjonktürün genişleme dönemlerinde vergi gelirlerinin artması nedeniyle bütçe fazla verdiğinde vergi yükünün azaltılması gerekirken, konjonktürün daralma döneminde vergi gelirlerinin azalması sonucu meydana gelen bütçe açı̆̆ının vergi oranları arttırılarak veya yeni vergiler konularak kapatılması zorunlu görülmüştür (Turhan, 1998: 277-278).

Liberal yaklaşımın aksine Keynesyen iktisatçılar ekonominin her zaman tam istihdamda dengeye gelemeyeceğini hatta bu dengesizliğin çok sık rastlanılan bir durum olduğunu savunmaktadırlar. Bu yaklaşıma göre kriz, özel tüketim ve yatırım harcamalarındaki dalgalanmaların neden olduğu efektif talep yetersizliğinden kaynaklanmaktadır. Devlet bu dalgalanmaları önlemek amacıyla maliye politikası araçlarını kullanarak ekonomiye müdahale etmelidir. Bu yüzden keynesyen düşünce kamu harcamaları ve vergilerin toplam talep üzerindeki etkilerine yoğunlaşmıştır.

Temeli J.M. Keynes zamanına dayanan modern konjonktür teorisine göre liberal yaklaşımın önerdiği şekilde uygulanan paralel bir vergi politikası, konjonktürel dalgalanmaları hafifletmenin aksine kuvvetlendirmektedir. Çünkü konjonktürün genişleme döneminde vergi yükünün azaltılması veya kamu harcamalarının arttırılması, toplam talebi arttırarak ekonomideki enflasyonist eğilimlerin daha da kuvvetlenmesine neden olur. Aynı şekilde durgunluk ve çöküntü dönemlerinde vergi yükünün arttırılması, özel tüketim ve yatırım faaliyetlerini azaltarak ekonomideki deflasyonist eğilimlerin hızlanmasına yol açtığı gibi, kamu harcamalarının azaltılması da konjonktürel daralma sürecini kuvvetlendirmektedir. Bu nedenle, liberal yaklaşımın aksine keynesyen iktisatçılar maddi anlamda bütçe denkliği yerine şekli anlamda bütçe denkliğini benimseyerek ekonomik istikrarı bozucu nitelikte olan konjonktürel dalgalanmaları maliye politikası araçlarıyla hafifletilmesini önermektedir (Turhan, 1998: 278). Devlet ekonomik kriz dönemlerinde vergi indirimine giderek kullanılabilir geliri arttırmalı ve azalan özel tüketim ve yatırım harcamalarının artışını teşvik etmelidir. Bu dönemden sonra maliye politikası aracı olarak vergilerle uygulanan konjonktür karşıtı 
Tabar Ç. \& M. Tokatlıoğlu (2018). “Küresel Ekonomik Kriz Döneminde Türkiye'de Uygulanan Vergi Politikalarının Değerlendirilmesi”, International Journal of Public Finance, Vol.3, No.1, pp. 27-46.

(countercyclical) politikalar ekonomik krizlerle mücadelede en çok başvurulan araçlardan biri olmuştur.

Monetarizm, arz yönlü iktisat, kamu tercihi teorisi ve yeni klasik iktisat gibi görüşlerin oluşturduğu neo-liberal yaklaşım ise krizin temel gerekçesi olarak devletin ekonomiye gereksiz ve yoğun müdahalesini göstermektedir. Bu yaklaşıma göre devletin ekonomiye müdahalesi düzgün işleyen piyasa ekonomisinin işleyişini bozmakta ve ekonomik istikrarsızlıklara neden olmaktadır. Bu nedenle söz konusu yaklaşımlar kamu kesiminin küçültülmesini ve devletin ekonomideki etkinliğinin azaltılmasını savunmaktadır. Ekonomide bir istikrarsızlık yaşansa bile bu serbest piyasa ekonomisi içinde kendiliğinden çözülecektir. Ekonomik istikrarsızlığı azaltmak amacıyla piyasaya dışarıdan yapılan müdahaleler istikrarsızlığı daha da arttırmaktadır. Bu nedenle neoliberal politikaları savunan görüşler ekonomik kriz dönemlerinde vergi politikası dahil hiçbir politikayla ekonomiye müdahale edilmemesi gerektiğini savunmaktadır.

Görülüğü gibi liberal yaklaşımların aksine keynesyen görüşe göre vergi politikası, ekonomik kriz dönemlerinde, ülke ekonomisi üzerinde yaratacağı etkilerle krizin neden olduğu olumsuzlukları ortadan kaldırmak için bir araç olarak kullanılabilir (Can, 2003: 69). Ekonomik kriz dönemlerinde vergi politikasının etkin kullanılabilmesi için ilk yapılması gereken, ekonominin mevcut durumu ve bu durumdan kaynaklanan gelişmelerin değerlendirilmesi açısından önemli olan göstergelerden hareket ederek zamanında, doğru bir teşhis ve tahminde bulunabilmektir (Turhan, 2002: 70).

Krize karşı uygulanacak vergi politikalarının genel makro dengeleri yeniden tesis etmeye, piyasalara güveni yerleştirmeye ve uzun vadede büyümeyi sağlamaya yönelik bir perspektife sahip olması gerekmektedir (Kızılot \& Durmuş, 2001:159-160). Dolayısıyla kriz dönemlerinde uygulanacak vergi politikası krizin ortaya çıkış nedenine göre farklılık göstermektedir. Ancak şunu da unutmamak gerekir ki; vergi politikasının, ekonomik krizlerin olumsuz etkilerini tek başına ortadan kaldırması mümkün değildir. Devletin para, faiz ve döviz kuru politikalarını vergi politikasıyla uyumlu biçimde kullanması gerekmektedir.

\section{Küresel Ekonomik Kriz ve Türkiye Ekonomisine Etkileri}

2007 yılının son çeyreğinde ABD ipotekli konut piyasasında baş gösteren sorunlar nedeniyle ortaya çıkan kriz, başlangıçta finansal kriz olarak kendini göstermiş daha sonra ise reel sektöre sıçramıştır. Küresel ekonomik krizin ortaya çıkışının birçok nedeni olmakla birlikte, temel nedenler olarak; likidite bolluğu ve özensiz krediler, aşırı menkul kıymetleştirme, saydamlık eksikliği ve asimetrik bilgi ve derecelendirme kuruluşlarının kendinden beklenen görevlerini yerine getirememesi olarak ifade edebiliriz (Alantar, 2008).

Küresel kriz öncesinde dünya ekonomisinde likiditenin arttığı görülmektedir. Bu artışa çeşitli ülkelerin uyguladıkları politikalar etkili olmuştur. 2001 yılında dünya ticaret örgütüne üye olunca Çin, uluslararası ticaretinde patlama yaşamıştır. Yuan'ın değerini 
Tabar Ç. \& M. Tokatlıoğlu (2018). “Küresel Ekonomik Kriz Döneminde Türkiye'de Uygulanan Vergi

Politikalarının Değerlendirilmesi”, International Journal of Public Finance, Vol.3, No.1, pp. 27-46.

düşük tutarak uluslararası pazarda rekabet gücünü arttırmıştır. Bu durum bir taraftan Çin'in hızlı bir şekilde büyümesi, ticaret fazlası vermesi ve tasarruf oluşturmasını sağlarken diğer taraftan da özellikle ABD'nin ticaret açıkları vermesine neden olmuştur (Ramadhan \& Naseeb, 2015: 2). ABD'de oluşan bu açıkların para basarak finanse edilmesi likidite artışının en temel nedeni olmuştur (Aslanoğlu, 2011: 37). Yine bazı ülkeler 1990'lı yılların sonunda yaşanan Asya krizine tepki olarak yatırım ve tüketim harcamalarını azaltıp, tasarruflarını arttırarak net finansal sermaye ihracatçısına dönüşmüşlerdir. Özellikle Uzakdoğu Asya ülkelerinde (özellikle Çin ve Japonya'da) yoğunlaşan bu tasarruflar, ABD'nin finansal araçlarına yönelen bir talep oluşturmuştur (Diamond \& Rajan, 2009: 606). 1990'larda spekülatif bir taleple yüksek faizli gelişmekte olan ülkelere akan bu tasarruflar, 2000'li yılların başından itibaren spekülatif amaçla değil, güvenli liman amacıyla ABD’ye akmış ve likiditeyi arttırmıştır (Yay, 2012: 446). Likiditenin bolluğu faiz oranlarının düşüşü yönünde bir baskı oluşturmuş, $A B D$ 'de kredi patlamasının yaşanmasını ve risk alma iştahının artmasını tetiklemiştir (Bario \& Disyatat, 2011:1). Bu dönemde likiditenin fazla olması ve faizlerin düşürülmesi sonucunda, finansal kuruluşlar tarafından kredi standartları gözetilmeden mortgage kredisi verilmiştir. Finansal kurumların kredi standartlarını çok gözetmeden yoğun bir şekilde mortgage kredileri dağıtmaları 2008 krizinin en önemli nedenleri arasında sayılmaktadır. Söz konusu kredilerin önemli bir kısmı ise, düşük gelirli kişilere verilen ve bu yüzden yüksek riskli olarak kabul edilen "sup-prime morgage" kredileri özelliği taşımaktadır.

2000'li yıllarda bankalar tarafından verilen mortgage kredilerinde büyük miktarda artış olması, mortgage fonlarının giderek bir menkul kıymet gibi ikincil piyasalarda daha fazla alım satıma konu olmasına yol açmıştır (Tarı \& Eraslan \& Bayraktar, 2011: 20-21). Küresel kriz öncesinde bireyler menkul kıymetleştirme sayesinde normalin çok daha üstünde kredi kullanmışlardır. Çünkü bu dönemde, menkul kıymetleştirme sayesinde dolaşım kabiliyeti olmayan finansal sözleşmelere dolaşım kabiliyeti kazandırılarak daha fazla mevduata gerek olmadan bankaların yeni kredileri finanse etme olanağı doğmuştur. Risk paylaşımı, yüksek getiri iştahı ve bankaların yasal sermaye yükümlülüklerini yerine getirmelerinde kolaylık sağlanması da menkul kıymetleştirmeyi özendirmiştir. Menkul kıymetleştirmenin krizin nedenleri arasında değerlendirilmesinin temel nedeni menkul kıymetleştirme sayesinde riskin bir kurumdan diğer bir kuruma aktarılmasının kolaylaşmasıdır (Alantar, 2008: 3). Çünkü kredi açan banka, riski başka kurumlara ve yatırımcılara transfer edebildiğinden, kredi başvurusunda bulunanların ödeme kapasitelerine yeterince hassasiyet gösterilmemiş ve küresel bir krize zemin hazırlanmıştır (Özsoylu \& Ünlükapan \& Gedik, 2010: 46-47).

Küresel kriz öncesinde yaşanan aşırı menkul kıymetleştirme süreci giderek karmaşıklaşan ve saydamlığı azalan yeni varlıkların ortaya çıkmasına neden olmuştur (Karaçor vd, 2012: 158). Bu dönemde yaşanan en büyük problemlerden biri bankaların ve aracıların sahip olduğu varlıkların türü, değeri ve hatta karşı tarafın ödeme riski hakkındaki şeffaflık eksikliğidir. Bu nedenle 2008 küresel krizinin altında yatan nedenlerden biri de asimetrik bilgidir. Türev ürünlerin tam olarak neyi içerdiğini bilmeyen ve balonlara dayalı bir saadet zinciri yarattığının farkına varamayan birçok kişi ve kurum daha fazla getiri elde etmek için bu ürünleri almaya yönelmiştir. Bu ürünlere 
yönelik talep artışı ise ürünlerin miktarının artmasına ve balonun giderek büyümesine neden olmuştur (Eğilmez, 2011: 96). Bu problemler nedeniyle, özellikle Lehman Brothers gibi türev diye adlandırılan karmaşık ticari sözleşmelere sahip şirketlerin iflasları sonucu ortaya çıkan riskin hesaplanması ve analiz edilmesi zorlaştırmıştır (Wasserstom, 2008).

Kriz öncesi dönemde derecelendirme kuruluşları asimetrik bilginin kaynağı olmuşlardır. Kredi derecelendirme kuruluşlarının değerlendirdiği ürünlerin \%98'inin, bu değerlendirme için gereken ücretini ürünü ihraç eden taraf tarafından ödenmesi ve aralarında bir iş ilişkisinin bulunması bu kuruluşların objektif değerlendirme yapmasını engellemiştir. Çünkü iş ilişkilerini devam ettirmek isteyen kuruluşlar kredi derecelerini yüksek tutmak zorunda kalmışlardır (Özdemir,2013:232). ABD'de derecelendirme kuruluşları aralarındaki iş ilişkisinden dolayı ve sektörün giderek büyümesine güvenerek yeterli bilgiye sahip olmadan mortgage fonlarına yüksek notlar vermişlerdir. Bu durum yatırımcıların mortgage fonlarına talebini arttırmış ve fonların değeri hızla yükselmiştir. Ancak 2007 yılında motgage kredilerinin bankalara geri ödenmesinde yaşanan problemler sonrasında derecelendirme kuruluşları, fonlar hakkında yeterli bilgi sahibi olmadan tüm mortgage fonlarına olumsuz notlar vermiştir. Bu da yatırımcıların paniğini arttırarak mortgage fonlarının elden çıkarılmasına yol açmıştır. Dolayısıyla gerçekte mali açıdan iyi durumda olan finansal kurumlar da ellerindeki mortgage fonlarını satamadıkları için likidite sıkıntısına girmişlerdir. Böylece 6 ay ile 1 yıl gibi kısa bir süre içerisinde tüm finansal sistemde likidite sıkışıklıkları, mevduat kaçışları ve kredi hacmi düşüşleri yaşanmış ve ekonomi finansal krize yakalanmıştır (Tarı vd, 2011: 2122).

Kriz mali piyasalar aracılı̆̆ıyla yayılmış ve krizden tüm ülkeler olumsuz etkilenmiştir. Ancak gelişmiş ülkeler ve özellikle Avrupa Birliği krizin en çok etkilediği ülkelerdir. Bunun nedenlerinden biri $A B D$ kaynaklı türev ürünlerin bu ülkelerin bankaları tarafından alınıp satılmasıdır. Söz konusu bu ürünlerde ortaya çıkan problemler Avrupa Birliği ( $A B)$ bankalarını ve finans sistemini olumsuz etkilemiştir. Bir diğer neden ise $A B^{\prime}$ nin en büyük ihracatçısı konumunda bulunan $A B D^{\prime}$ nin $A B^{\prime}$ den ithalat taleplerini azaltması sonucunda ihracatının olumsuz etkilenmesidir (Göçer, 2013: 171). Gelişmekte olan ülkelerin krizden etkilenmesi ise bu ülkelere gelen sıcak paranın azalmasına ve ihracatta yaşanan düşüşe bağlı olarak ortaya çıkmıştır. Sıcak paranın kaynağı olan gelişmiş ülkelerde sorunların gelişmekte olan ülkeleri de etkileyeceği korkusu, bu ülkelerdeki yabancı sermayenin hızla ülke dışına çıkmasına yol açmıştır. Bununla birlikte gelişmiş ülkelerdeki talebin düşmesi gelişmekte olan ülkelerin ihracatının azalmasına, işsizliğin artmasına ve krizin derinleşmesine neden olmuştur(Eğilmez, 2011: 69).

Türkiye'deki bankalar kanunen yabancı bankalara ait menkul kıymet ve türevlerini satın alamadığı için, gelişmiş ülkelerin yaşadığı ve $A B D$ 'deki finans sektöründe kıymetli kâğıtların değer kaybetmesinden kaynaklanan bir sorun yaşamamıştır. Ancak Türkiye krizden doğrudan etkilenen ülkelerle olan ticari ve finansal ilişkileri ile geleceğe yönelik olumsuz beklentiler ve piyasalarda oluşan 
Tabar Ç. \& M. Tokatlıoğlu (2018). “Küresel Ekonomik Kriz Döneminde Türkiye'de Uygulanan Vergi

Politikalarının Değerlendirilmesi”, International Journal of Public Finance, Vol.3, No.1, pp. 27-46.

güvensizlik sonucunda iç ve dış talepte görülen daralma ülke ekonomisini olumsuz etkilemiştir (Karaca, 2014: 272).

Küresel kriz Türkiye ekonomisini genel olarak dört kanaldan etkilemiştir. Bu kanalları; dış talepte daralma (dış ticaret kanalı), iç ve dış kredi kaynaklarında azalış, yabancı portföy yatırımlarında düşüş, yatırımcı ve tüketici güvenindeki azalışa bağlı olarak iç talep azalışı olarak sayabiliriz (Altınok \& Çelik \& Aktürk, 2011:190).

Küresel krizin Türkiye ekonomisine bulaşmasını sağlayan en önemli kanallardan biri dış ticaret kanalıdır. Kriz döneminde ekonomiler küresel düzeyde küçüldüğü için, küresel gelir düzeyi düşmüştür. Küresel gelir düzeyinin düşmesi talebi düşürücü etki ortaya çıkarmıştır (Özatay, 2011: 144). Dünya ticaret hacmi 2008'de \%15,4 büyürken, küresel krizin etkisiyle 2009 yılında \%22,8 oranında sert bir düşüş yaşamıştır. Bu durum öncelikle ihracata yönelik üretim yapan sektörlerde daralma yaşanmasına sebep olmuştur (Aras, 2010: 8). Türkiye'nin dış talep kanalından önemli ölçüde etkilenmesinin bir sebebi; ihracat yaptığı ülkelerin krizden en çok etkilenen ülkeler olmasıdır. Türkiye'nin ihracat hacminin neredeyse yarısı $A B$ üyesi ülkelerle yapılmaktadır. Küresel krizin kendisini en sert biçimde hissettirdiği bölgenin Avrupa kıtası olması ve $A B^{\prime}$ nin 2009 yılında \%4,2 oranında küçülmesi Türkiye'nin ihracatını olumsuz etkilemiştir. Çünkü $A B$ ülkelerinde yaşanan durgunluk, dış talebin daralmasına, bu ise Türkiye'nin $A B$ pazarına mal satamamasına neden olmuştur (Kutlay, 2009: 59). Türkiye'nin ihracatının olumsuz etkilenmesinin bir diğer nedeni ise döviz kurlarında yaşanan artış nedeniyle ithalatın pahalılaşmasıdır. Çünkü Türkiye imalat sanayi ve özellikle ihracatı, ithalata büyük ölçüde bağımlılık göstermektedir. Bu sebeple kriz ortaya çıkan kur artışı ithal girdi maliyetlerini arttırarak rekabet gücünü önemli oranda azaltmış ve ihracatı olumsuz etkilemiştir (Altınok vd., 2011:191).

Küresel krizde Türkiye'yi etkileyen bir diğer kanal kredi kanalıdır. Küresel kriz, finans sistemini çökme noktasına getirmiş, birçok banka batmış, kalanların büyük kısmı da önemli miktarda zarara uğramışlardır. Bu durum finansal kurumlar arasında güveni ortadan kaldırmış, belirsizlik son derece artmış ve ülkeler arası sermaye akımları önemli miktarda azalmıştır (Özatay, 2011:146). Bu dönemde Türkiye bankalarında 2001 krizinde olduğu gibi yapısal bozukluk yaşanmamıştır. Ancak sendikasyon kredilerinde ve döviz cinsinden borçlanmada zorluk yaşadıkları için bankaların dışarıdan elde ettiği fonlar azalmıştır. Çünkü Türkiye'de hem bankalar hem de şirketler, dışarıdaki batmış veya bilançosu önemli miktarda zarara uğramış bankalardan kredi kullanmışlardır. Bu kanalın kapanması yurt içi kredilerin hacmini daraltıcı etki yaratmıştır (TEPAV, 2009:4). Yurt içi kredi hacminin daralması yatırımların azalmasına neden olmuştur. Yatırımların azalması ise üretimin ve dolayısıyla işsizliğin artmasına yol açmıştır.

Krizin Türkiye ekonomisini etkilediği bir diğer kanal ise yatırım kanalıdır. Türkiye'nin sermaye açığının karşılanmasında önemli bir yere sahip olan doğrudan yabancı sermaye yatırımları ve portföy yatırımları krizin ortaya çıkardığı belirsizlik şartlarında azalış göstermiştir.

Krizin Türkiye'ye taşınmasına neden olan son kanal ise artan risk algılamasının üretici ve tüketici güvenini azaltması sonucunda yatırımcı ve tüketici davranışlarının 
olumsuz etkilenmesidir. Bu dönemde yaşanan belirsizlik sonucunda ilk olumsuz etkilenen kalem özel yatırım harcamaları olmuştur. Aynı dönemde ve ortamda tüketici psikolojisi ve dolayısıyla bekleyişleri olumsuz etkilenmiş ve dayanıklı tüketim mallarında hızı bir daralma yaşanmıştır (TEPAV, 2009: 4). Krizin Türkiye ekonomisinin makroekonomik göstergeleri üzerindeki etkisi ise aşağıda tablo 1'de gösterilmiştir.

Tablo 1: Türkiye Ekonomisine Ait Makroekonomik Veriler

\begin{tabular}{|c|c|c|c|c|}
\hline Yıllar & GSYH Değişim Oranı & İşsizlik Oranı & TÜFE & Bütçe Açığı/GSYH \\
\hline $\mathbf{2 0 0 5}$ & 8,4 & 9,5 & 7,7 & $-1,3$ \\
\hline $\mathbf{2 0 0 6}$ & 6,9 & 9,0 & 9,7 & $-0,6$ \\
\hline $\mathbf{2 0 0 7}$ & 4,7 & 9,2 & 8,4 & $-1,6$ \\
\hline $\mathbf{2 0 0 8}$ & 0,7 & 10,0 & 10,1 & $-1,8$ \\
\hline $\mathbf{2 0 0 9}$ & $-4,8$ & 13,1 & 6,5 & $-5,5$ \\
\hline $\mathbf{2 0 1 0}$ & 9,2 & 11,1 & 6,4 & $-3,6$ \\
\hline $\mathbf{2 0 1 1}$ & 8,8 & 9,1 & 10,5 & $-1,4$ \\
\hline $\mathbf{2 0 1 2}$ & 2,1 & 8,4 & 6,2 & $-2,1$ \\
\hline $\mathbf{2 0 1 3}$ & 4,2 & 9,0 & 7,4 & $-1,2$ \\
\hline $\mathbf{2 0 1 4}$ & 2,9 & 9,9 & 9,4 & $-1,3$ \\
\hline
\end{tabular}

Kaynak: TUiK, Hazine Müsteşarlığı, Yıllık Ekonomik Rapor 2014

Tablo 1'de de görüldügü gibi küresel ekonomik kriz Türkiye'nin makroekonomik göstergelerini olumsuz etkilemiştir. 2008 yılının son çeyreğinden itibaren başlayan ve 2009 yılında etkisini iyice gösteren kriz milli gelirin küçülmesine, işsizliğin artmasına ve kamu maliyesinin bozulmasına neden olmuştur. Buna göre 2009 yılında milli gelir \%4,8 oranında küçülmüş, işsizlik \%13,1 ve bütçe açığı \%5,5'e yükselmiştir. Küresel ekonomide yaşanan durgunluk ve emtia fiyatlarında yaşanan düşüşler ise Türkiye'de enflasyon oranlarının düşmesine neden olmuştur. 2009 yılında enflasyon oranı \%6,4 olarak gerçekleşmiştir.

\section{Küresel Ekonomik Krizde Türkiye'de Uygulanan Vergi Politikası Önlemleri ve Değerlendirilmesi}

Küresel ekonomik kriz tüm dünyayı etkisi altına alarak, ülke ekonomilerini olumsuz etkilerken, dünya ülkeleriyle ticari ve finansal bağları bulunan Türkiye ekonomisi de krizden nasibini almıştır. Ancak Türkiye'nin krizi algılamakta geciktiği söylenebilir. Nitekim 2009 bütçe çalışmaları sırasında büyüme tahmini \%4 olarak alınmıştır. Buna karşın, bu tahmin Nisan 2009 ortasında eksi \%3,6 olarak revize edilmiştir. Bu durum krize karşı alınacak tedbirlerin de gecikmesine neden olmuştur. Algılamadaki gecikmenin nedeni; krizin finansal kriz niteliği göstermesi sebebiyle, 2001 
Tabar Ç. \& M. Tokatlıoğlu (2018). “Küresel Ekonomik Kriz Döneminde Türkiye'de Uygulanan Vergi

Politikalarının Değerlendirilmesi", International Journal of Public Finance, Vol.3, No.1, pp. 27-46.

krizinden sonra Türkiye'de alınan tedbirler sonucu bankacılık sektörünün sağlamlığına güvenilmesi ve krizin daha çok gelişmiş ülkeleri etkileyeceği düşüncesidir. Ancak kriz Türkiye'yi daha çok reel kesim üzerinden olumsuz etkilemiştir. Olumsuz etkiler yaşanan belirsizlik ve güvensizlik ortamı nedeniyle yatırım ve tüketim kararlarında kendini göstermiştir. Kredi bulmakta yaşanan sıkıntılarla birlikte iç ve dış talep daralmasına bağlı olarak üretim düzeyi azalmış, ihracat düşmüş, işsizlik artmış ve büyüme gerilemiştir. Bunun üzerine, krizin üretim ve istihdam üzerindeki bu olumsuz etkilerinin azaltılması ve iktisadi durgunluğun giderilmesine yönelik tedbirler alınmıştır (Özsoylu vd, 2010: s.92).

Geçmiş deneyimler ve literatürün gösterdiği gibi, durgunluk krizinin yaşandığı dönemlerde genişletici maliye politikaları öne çıkmaktadır. Ancak, talep daralmasıyla kendini gösteren ve derinleşen kriz ortamından çıkışta genişletici maliye politikalarının para politikalarıyla da desteklenmesi kaçınılmazdır. Bu gerçekten hareketle Türkiye, 2008 kriziyle mücadelesinde para ve maliye politikalarını birlikte kullanmıştır (Selen, 2009: 259). Türkiye'nin krize karşı aldığı tedbirler ilk olarak diğer ülkelerde olduğu gibi; likidite desteği kredileri ( Cansuyu I-II), likidite maliyetini azaltan faiz indirimi vb. para politikası önlemleri şeklinde olmuştur (Karakurt, 2010: 186). Alınan önlemlerin yetersiz kalması sonucu maliye politikası önlemleri devreye sokulmuştur. Hükümetin bu tedbirleri almasındaki temel sebep hiç kuşkusuz kapasite kullanım oranlarındaki önemli düşüş ve işsizlik oranındaki önemli artıştır. Hükümetin krize karşı aldığı tedbirlerin büyük bölümü maliye politikası araçları yoluyla özellikle de vergi politikası aracılığıyla alınmıştır. (Çolak, 2009: 52-53) Bunun başlıca nedeni vergi gelirlerindeki düşme nedeniyle kaynak sıkıntısının yaşanmasıdır. Bu sebeple teşvikler, kamu harcamasından ziyade vergi indirimi ve prim indirimi olarak uygulanmıştır (Ercan \& Taymaz \& Yeldan, 2010: 75). Vergi indirimlerini içeren canlandırma paketleriyle kısa dönemde tüketimin arttırılarak ekonominin canlandırılması amaçlanırken, uzun dönemde yatırımları arttırarak üretim artışının sağlanması hedeflenmiştir. Uygulanan bu vergi politikası önlemlerini KDV ve ÖTV indirimleri, Varlık Barışı uygulaması ve diğer vergi politikası önlemleri olmak üzere üç başlıkta ele almak mümkündür.

\subsection{KDV ve ÖTV İndirimleri}

Vergi indirimleri ile ilgili ilk düzenleme, konut ve dayanıklı tüketim malları satışlarındaki gerilemenin önlenmesi için 16 Mart 2009 tarihli Resmi Gazetede yayınlanan “Bazı Mallara Uygulanacak Katma Değer Vergisi ve Özel Tüketim Vergisi Oranlarının Belirlenmesine ilişkin Bakanlar Kurulu Kararı"dır. Bu düzenleme ile 15 Haziran 2009'a kadar geçerli olmak üzere, net alanı 150 metre kare ve üzerinde bulunan konutlarda KDV oranı \%18'den \%8'e indirilmiştir. ÖTV oranları ise; beyaz eşya ve bazı elektronik eşyalarda \%6,7 oranından \%0'a, motor silindir hacmi $1600 \mathrm{cm3}$ 'ü geçmeyen otomobillerde \% 37'den \%18'e, motor silindir hacmi $1600 \mathrm{~cm} 3-2000 \mathrm{~cm} 3$ arasındaki otomobillerde $\% 60$ 'dan $\% 54$ 'e, kamyonlarda $\% 4$ 'ten $\% 1^{\prime}$ e, midibüslerde $\% 4$ 'ten $\% 1$ 'e, otobüslerde $\% 1$ 'den $\% 0$ 'a, minibüslerde $\% 9$ 'dan $\% 2$ 'ye, motosikletlerde \%22'den \%11'e indirilmiştir (2009/14802 Sayılı Bakanlar Kurulu Kararı). 
Daha sonra 29 Mart 2009 tarihli resmi gazetede yayınlanarak yürürlüğe giren yeni bir bakanlar kurulu kararıyla KDV indirimi uygulaması genişletilmiştir. Böylece 30 Haziran 2009'a kadar geçerli olmak üzere; bina ve bağımsız şekildeki işyerleri, ev ve ofis mobilyaları, bilişim ve büro makineleri, bazı sanayi ve iş makinelerinin satışından alınan KDV oranı \%18'den \%8'e düşürülmüştür (2009/14812 Sayılı Bakanlar Kurulu Kararı).

15 Haziran tarihinde sona eren ÖTV oran indirimleri ise yeniden belirlenerek 30 Eylül 2009 tarihine kadar uzatılmıştır. Böylece; motor silindir hacmi $1600 \mathrm{~cm} 3$ 'ü geçmeyen otomobillerde \% 37'den \%18'e indirilen ÖTV oranı \%27olarak, midibüsler ve kamyonlar için $\% 4$ 'ten $\% 1$ 'e indirilen ÖTV oranı $\% 2$ olarak, otobüslerde $\% 1$ 'den $\% 0$ 'a indirilen ÖTV oranı \%0 olarak, minibüslerde \%9'dan \%2'ye indirilen ÖTV oranı \%4 olarak, motosikletlerde \%22'den \%11'e indirilen ÖTV oranı \%16 olarak, beyaz eşyada \%6,7'den \%0'a indirilen ÖTV oranı ise \%2 olarak uygulanmıştır (2009/15081 Sayılı Bakanlar Kurulu Kararı).

Görüldüğü gibi yukarıda ifade edilen KDV ve ÖTV indirimleri krizden en çok etkilenen otomotiv, beyaz eşya, mobilya ve inşaat gibi sektörlere yönelik uygulanmıştır. Alınan bu önlemlerle söz konusu sektörlerin canlandırılması amaçlanmıştır. Bu çalışmada, diğer sektörlere yönelik veri bulma güçlüğü nedeniyle sadece otomotiv, beyaz eşya ve mobilya sektörü dikkate alınmış, otomotiv ve beyaz eşya sektörüne ilişkin satış ve mobilya sektörüne yönelik üretim verileri değerlendirilerek vergi indirimlerinin amacına ulaşıp ulaşmadığı incelenmiştir. Tablo 2, 2003 ve 2012 yılları itibariyle otomotiv piyasası satış rakamlarını ortaya koymaktadır. Bu rakamlar satılan otomobil ve hafif ticari araç, kamyon otobüs, midibüs gibi ticari motorlu araç sayısını göstermektedir.

Tablo 2: Türkiye Otomotiv Piyasasında 2003 - 2012 Dönemi Satış Rakamları

\begin{tabular}{|c|c|c|c|c|c|c|}
\hline \multirow{2}{*}{ YILLAR } & \multicolumn{7}{|c|}{ ÜRÜN TÜRÜ } \\
\cline { 2 - 7 } & Otomobil & $\begin{array}{c}\text { Hafif } \\
\text { Ticari Araç }\end{array}$ & Kamyon & Otobüs & Midibüs & Toplam \\
\hline 2003 & 227.038 & 137.033 & 30.098 & 1.051 & 2.743 & $\mathbf{3 9 7 . 9 6 3}$ \\
\hline 2004 & 451.209 & 248.888 & 37.205 & 1.503 & 2.464 & $\mathbf{7 4 1 . 2 6 9}$ \\
\hline 2005 & 438.597 & 271.811 & 41.982 & 1.498 & 4.649 & $\mathbf{7 5 8 . 5 3 7}$ \\
\hline 2006 & 373.219 & 244.833 & 42.071 & 1.466 & 3.926 & $\mathbf{6 6 9 . 9 1 5}$ \\
\hline 2007 & 357.485 & 237.297 & 34.185 & 1.413 & 3.825 & $\mathbf{6 3 4 . 2 0 5}$ \\
\hline 2008 & 305.998 & 188.025 & 28.260 & 1.468 & 2.793 & $\mathbf{5 2 6 . 5 4 4}$ \\
\hline 2009 & 369.819 & 187.307 & 14.915 & 1.376 & 2.452 & $\mathbf{5 7 5 . 8 6 9}$ \\
\hline 2010 & 509.784 & 251.129 & 28.382 & 1.409 & 2.468 & $\mathbf{7 9 3 . 1 7 2}$ \\
\hline 2011 & 593.519 & 270.920 & 40.792 & 2.437 & 3.199 & $\mathbf{9 1 0 . 8 6 7}$ \\
\hline 2012 & 556.280 & 221.481 & 34.365 & 2.410 & 3.084 & $\mathbf{8 1 7 . 6 2 0}$ \\
\hline
\end{tabular}

Kaynak: OSD Yayınları 
Tabar Ç. \& M. Tokatlıoğlu (2018). “Küresel Ekonomik Kriz Döneminde Türkiye'de Uygulanan Vergi

Politikalarının Değerlendirilmesi", International Journal of Public Finance, Vol.3, No.1, pp. 27-46.

Türkiye otomobil piyasasında satılan araç sayısı 2004 yılında bir önceki yıla göre yaklaşık iki kat artarak çok ciddi bir artış göstermiştir. 2005 yılında da bir miktar artan satış rakamları bu yıldan sonra düşme seyrine girmiştir. Küresel krizin etkilerinin önemli ölçüde hissedilmeye başladığı 2008 yılında ise toplam araç satış rakamları 526.544 adete kadar düşmüştür. 2009 yılında ise otomotiv sektörüne yönelik uygulanan ÖTV indirimleri faydasını göstermiş ve kriz yılı olmasına rağmen toplam araç satış rakamları 575.869' a yükselmiştir.

Tablo 2 incelendiğinde, ÖTV indirimlerinin uygulamaya girdiği 2009 yılında otomobil satışları önemli bir artış gösterirken; aynı durum ticari araç satış rakamlarında görülmemiş, tam tersi bir durum yaşanmıştır. Türkiye otomotiv piyasasında 2008 yılında 305.998 adet otomobil satılırken 2009 yılında \%20,8'lik bir artışla 369.819 adet otomobil satılmıştır. Ticari araç satış rakamlarının ise tamamında düşüş yaşanmıştır. Özellikle 2008 yılında 28.260 adet kamyon satılırken 2009 yılında 14.915 adet kamyon satılmış ve yaklaşık yarı yarıya bir azalma yaşanmıştır. Otomobil satışlarında yaşanan artışın ticari araç satışlarında yaşanmaması, ÖTV indirimlerinin bireysel tüketicilerin kararları üzerinde rol oynadığını göstermektedir. Çünkü otomobil kullanıcıları genellikle işletmelerden ziyade bireysel tüketicileridir (Kartal, 2011: 253). Bir diğer neden ÖTV oran indirimlerinin otomobillerde ticari araçlara göre daha yüksek olmasıdır. Ticari araçlarda en yüksek oran indirimi minibüslerde 7 puan iken $1600 \mathrm{~cm} 3$ 'ü geçmeyen otomobillerdeki oran indirimi 19 puandır. Otomobiller için uygulanan bu önemli 19 puanlık indirim bireysel tüketiciler tarafından bir fırsat olarak görülmüş ve satış rakamlarını arttırmıştır.

Yukarıdaki veriler göz önüne alındığında otomobillere yönelik uygulanan ÖTV indiriminin amacına ulaştığı söylenebilir. Ancak genellikle ticari işletmeler tarafından kullanılan ticari araçlara yönelik uygulanan ÖTV indirimlerinin, işletmelerin kriz dönemlerinde oluşan geleceğe yönelik olumsuz bekleyişleri nedeniyle etkili olamadığı görülmektedir. Buradan varılan sonuç; özel tüketim artışını hedefleyen vergi teşviklerinin nihai tüketiciye verilmesi ve tüketim koşuluyla sağlanması hedefe yönelik başarıyı arttırmaktadır (Kartal, 2011: 253-254). Nitekim ekonomide düzelmelerin başladığı 2010-2012 arası ticari araç satış rakamlarında önemli artışlar yaşanması bunu doğrulamaktadır.

Beyaz eşya sektörüne bakıldığında ise ÖTV indirimlerinin 2009 yılındaki etkisini aşağıdaki Tablo 3 bize göstermektedir.

2009 yılında aylara göre buzdolabı, derin dondurucu, çamaşır makinesi, kurutucu, bulaşık makinesi ve fırın olmak üzere altı adet ürünün satış rakamları verilmiştir. Bu altı ürünün toplam yurtiçi satış rakamı şubat ayında 228.314 iken mart ayında 351.838'e yükselmiştir. Kuşkusuz bu artışın en önemli nedeni o tarihte yürürlüğe giren ÖTV indirimidir. ÖTV indirimi mart ayının ortasında başlamasına rağmen satışlar bir önceki aya göre \%54 oranında artış göstermiştir. ÖTV indirimlerinin etkisi nisan ayında da devam etmiş; şubat ayına göre \% 81 artışla 413.458'e mayıs ayında ise \%145 artışla 561.333'e ulaşmıştır. Beyaz eşya satışları Mayıs ayında 561.333 ile 2009 yılının en yüksek rakamına ulaştıktan sonra eylül ayına kadar bir düşüş eğilimine girmiştir. ÖTV indiriminin eylül ayında sona ermesiyle satış rakamlarında 
Tabar Ç. \& M. Tokatlıoğlu (2018). “Küresel Ekonomik Kriz Döneminde Türkiye'de Uygulanan Vergi Politikalarının Değerlendirilmesi", International Journal of Public Finance, Vol.3, No.1, pp. 27-46.

önemli miktarda düşüş yaşanmıştır. Eylül ayına göre ekim ayında \%20, kasım ayında \%22 ve aralık ayında \%31 düşüş yaşanmıştır. Bu bağlamda tablodaki veriler değerlendirildiğinde beyaz eşya sektörüne uygulanan ÖTV oran indirimlerinin amacına hizmet ettiği anlaşılmaktadır.

Tablo 3: 2009 Yılı Yurtiçi Beyaz Eşya Satış Rakamları

\begin{tabular}{|c|c|c|c|c|c|c|c|c|c|c|c|c|}
\hline \multicolumn{10}{|c|}{2009} \\
\hline İç Satış & Ocak & Şubat & Mart & Nisan & Mayıs & Haziran & Temmuz & Ağustos & Eylül & Ekim & Kasım & Aralık \\
\hline Buzdolabı & 70.229 & 61.450 & 101.608 & 114.376 & 166.750 & 163.049 & 178.756 & 159.767 & 169.025 & 105.533 & 132.752 & 91.129 \\
\hline $\begin{array}{c}\text { Derin } \\
\text { Dondurucu }\end{array}$ & 4.496 & 11.343 & 5.246 & 16.865 & 11.671 & 15.310 & 18.888 & 18.422 & 23.955 & 31.284 & 19.337 & 11.374 \\
\hline $\begin{array}{c}\text { Çamaşır } \\
\text { Makinası }\end{array}$ & 71.900 & 65.731 & 99.950 & 113.483 & 160.787 & 152.965 & 125.623 & 113.827 & 138.769 & 119.723 & 119.560 & 115.025 \\
\hline Kurutucu & 2.163 & 1.645 & 3.110 & 5.834 & 2.553 & 1.358 & 953 & 2.632 & 13.504 & 11.524 & 6.870 & 10.053 \\
\hline $\begin{array}{c}\text { Bulaşık } \\
\text { Makinası }\end{array}$ & 51.204 & 56.122 & 97.386 & 111.851 & 141.235 & 135.120 & 105.043 & 88.832 & 125.151 & 95.678 & 92.862 & 90.967 \\
\hline Fırın & 24.107 & 32.023 & 44.538 & 51.049 & 78.337 & 76.776 & 63.711 & 53.264 & 69.013 & 63.777 & 49.270 & 51.799 \\
\hline TOPLAM & $\mathbf{2 2 4 . 0 9 9}$ & $\mathbf{2 2 8 . 3 1 4}$ & $\mathbf{3 5 1 . 8 3 8}$ & $\mathbf{4 1 3 . 4 5 8}$ & $\mathbf{5 6 1 . 3 3 3}$ & $\mathbf{5 4 4 . 5 7 8}$ & $\mathbf{4 9 2 . 9 7 4}$ & $\mathbf{4 3 6 . 7 4 4}$ & $\mathbf{5 3 9 . 4 1 7}$ & $\mathbf{4 2 7 . 5 1 9}$ & $\mathbf{4 2 0 . 6 5 1}$ & $\mathbf{3 7 0 . 3 4 7}$ \\
\hline
\end{tabular}

Kaynak: Türkiye Beyaz Eşya Sanayicileri Derneği

ÖTV indiriminin son ayı olan eylülde, tüm ürünlerin satışında bir önceki aya göre kayda değer bir artış görülmektedir. Bu durum, ÖTV indiriminin bir fırsat olarak görüldüğünü ve bu fırsatı kaçırmak istemeyen vatandaşların son ayda beyaz eşya satın almaya yöneldiğini göstermektedir. Tablo 3'ten görüldüğü üzere beyaz eşya satışlarının en yüksek olduğu aylar sırasıyla mayıs ve hazirandır. Bu aylarda yüksek satış rakamlarına ulaşılmasında ÖTV indirimin yanı sıra düğün hazırlıklarının yapıldığı bir dönem olması da etki etmiştir. Tablo 3'te dikkat çeken bir diğer konu ihtiyaç oranı daha düşük olan ve pazar payı daha az olan ürünlerdeki satışların artış oranları daha fazladır.

Tablo 4'de Türkiye'de 2008-2013 yılları arasında aylara göre mobilya imalatı sektörünün kapasite kullanım oranları verilmiştir. Kapasite Kullanım Oranı, bir üretim birimi tarafından belirli bir dönem içerisinde fiilen gerçekleştirilen üretim miktarının fiziki olarak üretebileceği en yüksek miktara olan oranını göstermektedir (Eğilmez, 2015: 1).

Tablo 4'e bakıldığında Türkiye'de mobilya imalatı sektörü genellikle üretim kapasitesini \%70'in altında bir seviyede kullanmaktadır. Küresel Krizin yaşandığı dönemde mobilya sektörünün kapasite kullanım oranı \%58,2' ye kadar düşmüştür. Bunun en önemli nedeni talep yetersizliğidir. Çünkü üretimin yapılması talebe bağlıdır. Eğer talep varsa üretim de olur. Bu dönemde küresel ekonomide yaşanan durgunluk mobilya sektörünü de etkilemiş iç ve dış talepte yaşanan gerileme üretim miktarının düşmesine neden olmuştur. 
Tabar Ç. \& M. Tokatlıoğlu (2018). “Küresel Ekonomik Kriz Döneminde Türkiye'de Uygulanan Vergi Politikalarının Değerlendirilmesi", International Journal of Public Finance, Vol.3, No.1, pp. 27-46.

Tablo 4: Türkiye'de Mobilya İmalatı Sektörü Kapasite Kullanım Oranları

\begin{tabular}{|c|c|c|c|c|c|c|}
\hline & $\mathbf{2 0 0 8}$ & $\mathbf{2 0 0 9}$ & $\mathbf{2 0 1 0}$ & $\mathbf{2 0 1 1}$ & $\mathbf{2 0 1 2}$ & $\mathbf{2 0 1 3}$ \\
\hline Ocak & 62,8 & 58,2 & 64,8 & 70,1 & 69,0 & 68,3 \\
\hline Şubat & 67,9 & 58,3 & 66,8 & 68,6 & 69,8 & 68,9 \\
\hline Mart & 69,5 & 60,1 & 68,7 & 69,2 & 69,8 & 70,6 \\
\hline Nisan & 66,6 & 60,7 & 68,9 & 71,1 & 71,6 & 71,6 \\
\hline Mayıs & 70,7 & 69,9 & 73,1 & 72,1 & 68,8 & 73,9 \\
\hline Haziran & 74,9 & 75,6 & 72,1 & 73,1 & 69,3 & 71,4 \\
\hline Temmuz & 70,8 & 73,5 & 74,3 & 75,3 & 71,8 & 72,4 \\
\hline Ağustos & 70,9 & 70,3 & 69,6 & 76,0 & 67,5 & 72,5 \\
\hline Eylül & 71,3 & 71,9 & 72,5 & 75,5 & 69,9 & 72,3 \\
\hline Ekim & 65,2 & 69,9 & 72,3 & 74,8 & 69,8 & 72,0 \\
\hline Kasım & 67,4 & 67,7 & 72,0 & 72,9 & 70,8 & 72,3 \\
\hline Aralık & 64,0 & 66,7 & 70,1 & 72,2 & 69,9 & - \\
\hline Ortalama & $\mathbf{6 8 , 5}$ & $\mathbf{6 6 , 9}$ & $\mathbf{7 0 , 4}$ & $\mathbf{7 2 , 6}$ & $\mathbf{6 9 , 8}$ & $\mathbf{7 1 , 5}$ \\
\hline
\end{tabular}

Kaynak: TÜiK

Tablo 4'ten görüldüğü üzere Küresel Krizin etkisiyle 2008 yılının eylül ayından itibaren mobilya sektörü kapasite kullanım oranı düşüş eğilimine girmiştir. Eylül ayında \%71,3 olan mobilya sektörü kapasite kullanım oranı 2008 yılının aralık ayında \%64'e gerilemiştir. Düşme eğilimi 2009 yılında da devam etmiş, Ocak ayında \%58,2 ve Şubat ayında 58,3 olarak gerçekleştirmiştir. Mart ayının ortasından itibaren hükümet tarafından mobilya sektörünü de içeren vergi indirimlerinin uygulamaya girmesiyle birlikte iç talep artışına bağlı olarak üretimde artışlar görülmüştür. Bu dönem içerisinde mobilya sektörü kapasite kullanım oranları Mart ayında \%60,1'e, Nisan ayında \% 60,9'a, Mayıs ayında \%69,9'a ve Haziran ayında \% 75,6'ya yükselerek 2009 yılının en yüksek oranına ulaşmıştır. Ancak vergi indirimlerinin sona ermesiyle birlikte mobilya üretiminde tekrar düşüş başlamıştır. Mobilya sektörü kapasite kullanım oranları temmuz ayında \%70,5'e, ağustos ayında \%70,3'e ve 2009 yılının aralık ayında \% 66,7'ye düşerek yılı \%66,9 ortalamasıyla kapatmıştır.

Vergi indiriminin uygulandığı döneme bakıldığında mayıs ve haziran ayındaki üretim artışlarının mart ve nisan ayına göre daha fazla olduğu görülmektedir. Bu durumu iki sebebe bağlayabiliriz. Birincisi, mart ve nisan ayında vergi indirimi nedeniyle oluşan ek talebin kriz nedeniyle durgunluk yaşayan mobilya sektöründe artan stoklardan karşılandığı; ikincisi, vergi indirimleri sonucu artan talebe ek olarak mayıs ve haziran ayının düğün hazırlıkları yapılan bir döneme denk gelmesidir. 2008 ve 2013 yılları arasında haziran ayının kapasite kullanım oranlarına bakıldığında en yüksek orana 2009 yılında ulaşıldığı görülmektedir. Söz konusu yıllar arasında haziran ayında en yüksek orana kriz yılı olmasına rağmen 2009 yılında ulaşılmış olması mobilya sektörüne yönelik vergi indirimlerinin amacına ulaşmış olduğunu göstermektedir. 
Tabar Ç. \& M. Tokatlıoğlu (2018). “Küresel Ekonomik Kriz Döneminde Türkiye'de Uygulanan Vergi

Politikalarının Değerlendirilmesi", International Journal of Public Finance, Vol.3, No.1, pp. 27-46.

\subsection{Varlık Barışı Uygulaması}

Ülkelerin ekonomik krizlerle mücadele edebilmesi için kaynağa ihtiyaçları vardır. Buna karşılık, küresel kriz döneminde Türkiye ekonomisinde yaşanan durgunluk ve işsizlik vergi gelirlerinin azalmasına, krizin olumsuz etkilerini hafifletebilmek amacıyla uygulanan kriz karşıtı politikalar kamu harcamalarının artmasına, yabancı kaynak girişinin azalması ve ihracatın daralması dövize olan ihtiyacın artmasına neden olmuştur. Bu bağlamda, gereken kaynak ihtiyacını karşılayabilmek amacıyla kamuoyunda "Varlık Barışı" olarak adlandırılan bir yasal düzenleme yapılmıştır. Yapılan düzenlemeyle gerçek ve tüzel kişilerce, 1 Ekim 2008 tarihi itibariyle sahip olunan ve yurt dışında bulunan; para, altın, döviz, menkul kıymet ve diğer sermaye piyasası araçları ile varlığı bir belgeyle ispatlanabilen taşınmazların beyan edilen değerleri üzerinden \%2 oranında vergi alınması öngörülmüştür. Böylece söz konusu sermaye piyasası araçları ve taşınmazların milli ekonomiye kazandırılması ve yurt içinde bulunan ancak işletmelerin öz kaynaklarında yer almayan bu tür varlıkların sermayelerine eklenerek sermaye yapılarının güçlendirilmesi hedeflenmiştir.

Ayrıca gelir ve kurumlar vergisi mükelleflerince sahip olunan ve Türkiye'de bulunan fakat 1 Ekim 2008 itibariyle kanuni defter kayıtlarında işletmenin öz kaynakları arasında yer almayan para, altın, döviz, menkul kıymet ve diğer sermaye piyasası araçları ile taşınmazların beyan edilen değerleri üzerinden \%5 oranında vergi alınması kabul edilmiştir.

Bu kanun kapsamında bildirilen ve beyan edilen varlıklar hakkında 1 Ekim 2008 tarihinden önceki dönemlere ilişkin hiçbir suretle vergi incelemesi ve vergi tarhiyatı yapılmaması, yurt dışından elde edilen ticari kazançların 31 Mayıs 2009 tarihine kadar Türkiye'ye transfer edilmesi halinde gelir ve kurumlar vergisinden muaf olması sağlanmıştır. Ancak yurt içinden ve dışından beyan edilecek varlıklara yönelik uygulanan vergi oranlarının farklılık göstermesi kanunun öncelikli hedefinin yurt dışındaki varlıklar olduğunu göstermektedir. Böylece ekonominin dövize olan ihtiyacı azaltılmaya çalışımıştır.

Varlık Barışı uygulamasını değerlendirebilmek için Gelir İdaresi Başkanlığı'nın yayınladığı verilere bakmak gerekir. Buna göre "Varlık Barışı" kapsamında 10 Şubat 2010 tarihi itibariyle 48.258.116.475 TL tutarında varlık beyan edilmiş ve 1.576.625.305 TL vergi ödenmiştir. Ödenen vergi, beyan edilen tutarın \%3,3'üne tekabül etmektedir. Varlık Barışı uygulamasında verilen toplam beyanname sayısı 64.567'dir. Beyan edilen varlıkların 27.876.017.400 TL'si yurtdışından 20.382.099.075 TL'si yurt içinden beyan edilmiştir.

Aşağıdaki Tablo 5'te varlık barışı uygulaması kapsamında verilen beyannamelerin türüne göre beyannamelerin sayısı, tutarı ve toplam tutar içindeki payları gösterilmektedir. Verilere bakıldığında, 54.958 adetle en fazla TL cinsinden beyanname verilmiştir. TL'yi sırasıyla 7.135 adet ile döviz, 3.863 adet ile taşınmaz mallar, 407 adet ile altın ve 307 adet ile menkul sermaye izlemiştir. En fazla 
beyanname verilen varlık türü TL olmasına rağmen verilen toplam beyanname tutarı en yüksek olan varlık türü dövizdir. Döviz, varlık barışı uygulaması kapsamında toplam beyan edilen varlık tutarlarının $\% 51,5^{\prime}$ ini oluşturarak toplam tutarın yarısından fazlasına tekabül etmektedir.

Tablo 5: 5811 Sayılı Bazı Varlıkların Milli Ekonomiye Kazandırılması Kanununa İlişkin Bilgiler

\begin{tabular}{|c|c|c|c|}
\hline Varlık Türü & Beyanname Sayısı & Beyanname Tutarı (TL) & Oranı \\
\hline TL & 54.958 & 14.083 .892 .247 & 29,2 \\
\hline Döviz & 7.135 & 24.859 .193 .116 & 51,5 \\
\hline Altın & 407 & 3.243 .013 .674 & 6,7 \\
\hline Menkul Sermaye & 372 & 3.092 .207 .735 & 6,4 \\
\hline Taşınmaz Mal & 3.863 & 2.979 .809 .703 & 6,2 \\
\hline
\end{tabular}

Kaynak: GiB

\subsection{Diğer Vergi Politikası Önlemleri}

KDV ve ÖTV indirimleri ve Varlık Barışı uygulamasının yanı sıra, küresel krizin olumsuz etkilerini hafifletmek amacıyla başka vergi politikası tedbirlerine de başvurulduğu görülmektedir (T.C. BAŞBAKANLIK HAZINE MÜSTEŞARLIĞI, 2009). Bu önlemleri şu şekilde belirtmek mümkündür:

- 1 Eylül 2008 tarihi itibari ile vadesi geldiği halde ödenmemiş kamu alacakları için tecil ve taksitlendirme getirilmiştir (Bağımsız Sosyal Bilimciler,2011:171174). Mükelleflere eşit taksitlerle ödenmek üzere 18 aylık ödeme süresi tanınmıştır. Uygulanacak tecil faizi yıllık \%3'tür. 5 Aralık 2008'e kadar süren başvuru döneminde 1 milyon 520 bin vergi borçlusu tecil talebinde bulunmuş, bu mükellefler 7 milyar 598 milyon TL'si vergi aslı 3 milyar 721 milyon TL'si de faiz ve gecikme zammından oluşan toplam 11 milyar 520 milyon TL'lik vergi borcunun taksitlendirilmesini istemişlerdir.

- -Hisse senedi alım satımlarında yerli yatırımcılar tarafından elde edilen kazançlara yönelik uygulanan vergi oranı Bakanlar Kurulu kararı ile sıfıra indirilmiştir. 2006 yazındaki ani sermaye çıkışları nedeniyle yabancılar için indirilmiştir. Bu düzenleme ile yerli-yabancı ayrımı ortadan kaldırılmıştır.

- Yurt dışı tedarikçilerden sağlanan kredilerde stopaj oranı \%5' e indirilmiştir.

- Özel iletişim vergisi \%15' ten \%5' e indirilmiştir.

- КОВі birleşmelerini teşvik etmek amacıyla, 31.12.2009 tarihine kadar birleşen ve kanunda belirtilen koşulları sağlayan KOBi' lere, kurumlar vergisi muafiyeti ve \%75' e kadar indirimli kurumlar vergisi uygulanmasından faydalanabilme olanağı sağlanmıştır. 
- Menkul kıymet yatırım fonları ile menkul kıymet yatırım ortaklıklarının sermaye piyasalarında yaptıkları işlemler nedeniyle elde ettikleri gelirlere Banka ve Sigorta Muameleleri Vergisi muafiyeti getirilmiştir.

- Tarım Ürünleri Lisanslı Depoculuk Kanunu kapsamında düzenlenen ürün senetlerinin elden çıkarılmasından doğan kazançlara 31.12.2014 tarihine kadar gelir ve kurumlar vergisi muafiyeti getirilmiştir.

- 1979 veya daha eski model motorlu taşıtların30 Haziran 2010'a kadar kayıt ve tescillerinin silinmesi veya hurdaya çıkarılması karşılı̆ında, tahakkuk etmiş ve ödenmemiş motorlu taşıtlar vergisi ile bu vergiye ilişkin gecikme zammı, vergi cezaları ve plakaya kesilen cezalar silinmiştir.

- Konut, işyeri ve diğer gayrimenkullerin satışında alıcı ve satıcının her birinden binde 15 oranında alınan tapu harcı, 3 ay süreyle binde 5'e indirilmiştir.

Gerçek kişilere kullandırılan kredilerdeki Kaynak Kullanımını Destekleme Fonu (KKDF) kesintisi oranı \%15'ten \%10'a indirilmiştir.

\section{Sonuç}

Ekonomik krizlerin ortaya çıktığı ülkeler hem ekonomik hem de sosyal açıdan olumsuz etkilenmektedirler. Finansal piyasaların küreselleşmesi bu olumsuz etkilerin bir ülkeden diğerine kolayca bulaşmasına yol açabilmektedir. Nitekim 2008 yılında ABD'de ortaya çıkan ve mali piyasalar aracılığıyla tüm dünyayı etkisi altına alan Küresel Kriz Türkiye'yi de olumsuz etkilemiştir. Türkiye, gelişmiş ülkelerin yaşadığı ve ABD'deki finans sektöründe kıymetli kâğıtların değer kaybetmesinden kaynaklanan bir sorun yaşamamıştır. Ancak, krizden doğrudan etkilenen ülkelerle (özellikle de Avrupa Birliği ülkeleri ile) olan ticari ve finansal ilişkileri ile geleceğe yönelik olumsuz beklentiler ve piyasalarda oluşan güvensizlik sonucunda iç ve dış talepte yaşanan daralma ülke ekonomisini olumsuz etkilemiştir. Söz konusu kriz, 2001 krizinden sonra güçlendirilen finans sektörü nedeniyle finans sektöründen ziyade ekonomik büyüme, işsizlik gibi makroekonomik göstergeleri bozmuş daha çok reel ekonomi üzerinde etkili olmuştur. Krizin bu olumsuz etkilerinin hafifletilmesi için ağırlıklı olarak vergi politikası önlemleri olmak üzere birçok tedbir alınmıştır.

Türkiye'nin krize karşı aldığı tedbirler ilk olarak diğer ülkelerde olduğu gibi; likidite desteği kredileri, likidite maliyetini azaltan faiz indirimi vb. para politikası önlemleri şeklinde olmuştur. Bu önlemlerin yetersiz kalması sonucu maliye politikası önlemleri devreye sokulmuştur. Hükümetin bu tedbirleri almasındaki temel sebep kapasite kullanım oranlarındaki önemli düşüş ve işsizlik oranındaki önemli artıştır. Maliye politikası önlemlerinin büyük bölümü vergi politikası önlemlerinden oluşmaktadır. Bunun başlıca nedeni vergi gelirlerindeki düşme nedeniyle kaynak 
sıkıntısının yaşanmasıdır. Bu sıkıntıyı aşmak üzere teşvikler, kamu harcamasından ziyade vergi indirimi ve prim indirimi olarak uygulanmıştır. Vergi indirimlerinin önemli bir kısmı harcama vergilerinde (KDV ve ÖTV) gerçekleşmiştir. Bu indirimler krizden en çok etkilenen otomotiv, beyaz eşya, mobilya ve inşaat gibi sektörlere yönelik uygulanmıştır. Alınan bu önlemlerle söz konusu sektörlerin canlandırılması amaçlanmıştır. Uygulama sonuçlarına bakıldığında vergi indirimleri ilgili sektörlerde satışları ve/veya üretimi arttırıcı etkiler yaratmıştır. Bunda en büyük etken, vergi indirimlerinin nihai tüketiciyi hedef alacak şekilde uygulanmasıdır. Kamu mali dengesinin aşırı bozuk olmadığı şartlarda hükümetin böyle bir vergi indirimi politikasını uygulayabilme imkanını elde ettiğini göz ardı etmemek gerekir. Ülkeler ekonomik krizlerle karşılaştıklarında kamu maliyesi ne kadar güçlü ise krizlere karşı uyguladığı politikaların başarı şansı da o ölçüde artacak demektir.

\section{Kaynakça}

Afşar, A. (2011). Global Kriz ve Türkiye Konut Piyasasına Etkileri, Eskişehir, Anadolu Üniversitesi Yayınları No:2251.

Altınok, S., Çelik, F. \& Aktürk, O. (2011). "2008 Küresel Ekonomi Krizinin Türkiye Ekonomisine Illetim Kanalları ve İmalat Sanayine Etkileri", Küresel Ekonomik Kriz ve Finansal Kriz Türkiye Ekseninde Sorunlar ve Çözüm Önerileri, (Ed.) Çetinkaya M., Ankara, Nobel Yayıncılık, ss.187-215.

Alantar D. (2008). Küresel Finansal Kriz: Nedenleri ve Sonuçları Üzerine Bir Değerlendirme, Maliye Finans Yazıları, http://www.finanskulup.org.tr/assets/ maliyefinans/81/Dogan_Alantar_Kuresel_Finansal_Kriz_Nedenleri_Sonuclari_ MFY81.pdf, (30.04.2015).

Aras, O. N. (2010). “Türkiye'ye Makro Ekonomik Etkileri Bakımından 2008 Küresel Krizi", Finans Politik\& Ekonomik Yorumlar, 47(550), ss.5-18.

Aslanoğlu, E. (2011). "Küresel Ekonomik Kriz ve İktisat Politikaları", Zor Zamanlarda İktisat, (Ed.) Özgür G. \& Yetkiner H., Ankara, Efil Yayınevi, ss.35-44.

Bağımsız Sosyal Bilimciler (2011). Türkiye'de ve Dünyada Ekonomik Bunalım, 20082009, İstanbul, Yordam Kitap.

Bario C. \& Disyatat P. (2011). "Global İmbalances and the Financial Crisis: Link or No Link?", BIS Working Papers, No: 346, http://www.bis.org/publ/work346.pdf (08.07.2015)

Can, ì. (2003). "Ekonomik Krizlere Karşı Uygulanması Gereken Vergi Politikası", Maliye Dergisi, (42), ss.69-107.

Çolak, Ö. F. (2009). "Krizi Çözmede Maliye Politikaları Nasıl Kullanılmalı?”, İ̧̧veren Dergisi, C.47, S.6, http://www.tisk.org.tr/isveren (Erişim 30.04.2015) 
Diamondand D.W. \& Rajan, R.G. (2009). "The Credit Crisis: Conjontures about Causesand Remedies", American Economic Review, V.99, No.2, ss.1-17 http://citeseerx.ist.psu.edu/viewdoc/download?doi=10.1.1.320.2688\&rep=re p1\&type=pdf (29.11.2017)

Ercan H., Taymaz, E. ve Yeldan, E. (2010) Kriz ve Türkiye: Kriz Tedbirlerinin Etki Değerlendirilmesi, Ankara, ILO.

Erginay, A. (2003). Kamu Maliyesi, Ankara, Savaş Yayınları.

Eğilmez, M. (2015). Kapasite Kullanımı Nedir, Nasıl Ölçülür, Ne İşe Yarar?, http://www.mahfiegilmez.com/2012/03/kapasite-kullanm-nedir-nasl-olculurne.html (08.07.2015)

Eğilmez, M. (2011). Küresel Finans Krizi, 8.b., İstanbul, Remzi Kitapevi.

Göçer, i. (2013). "Küresel Ekonomik Krizin Etkileri: Panel Veri Analizi”, Balıkesir Üniversitesi Sosyal Bilimler Enstitüsü Dergisi, 16 (29), ss.163-188.

Karaca, C. (2014), "Uygulanan Para ve Maliye Politikaları Açısından Geçmiş Krizler ve 2008 Küresel Ekonomik Krizinin Karşılaştırmalı Analizi”, Çankırı Karatekin Üniversitesi Sosyal Bilimler Enstitüsü Dergisi, 5(1), ss.263-286.

Karaçor, Z., Alptekin, V. \& Gökmenoğlu, K. (2012). Finansal Kriz Üzerine Öngörülebilirlik ve Politikalar, Konya, Çizgi Kitapevi.

Karakurt, B. (2010). "Küresel Mali Krizi Önlemede Maliye Politikasının Rolü ve Türkiye'nin Krize Maliye Politikası Cevabı", Atatürk Üniversitesi IiBF Dergisi, 24 (2), 167-195.

Kartal, Z. (2011). “ Mali Krize Karşı Getirilen Vergisel Düzenlemelerin Etkinliğinin Değerlendirilmesi”, 25. Maliye Sempozyumu: Kriz Ortamında Vergi politikalarının Değerlendirilmesi, 25-28 Mayıs, Antalya, Yaklaşım Yayıncılık, ss.248-264.

Kızılot, Ş. \& Durmuş, M. (2001). “Kriz Döneminde Vergi Politikası Nasıl Olmalı?”, Gazi Üniversitesi iktisadi ve Idari Bilimler Fakültesi Dergisi, (2) 159-176.

Kibritçioğlu, A. (2001). "Türkiye'de Ekonomik Krizler ve Hükümetler 1969-2001", Yeni Türkiye Ekonomik Kriz Özel Sayısı I, S.41, Yıl 7, ss.174-182.

Kutlay, M. (2009). Küresel Finansal Krizin Türk Ekonomisine Etkileri: Türkiye'nin Kalkınması Önünde Engel mi, Fırsat mı?, Stratejik Boyut, Ağustos-Eylül-Ekim.

Oktar, S. \& Dalyancı, L., 2010, Finansal Kriz Teorileri ve Türkiye Ekonomisinde 1990 Sonrası Finansal Krizler, Marmara Üniversitesi iiBF Dergisi, 29(2), ss.1-22.

Özatay, F. (2011). Finansal Krizler ve Türkiye, İstanbul, Doğan Kitap.

Özdemir, B. K. (2013). Finansal Küreselleşme ve Krizler, Ankara, Seçkin Yayıncılık.

Özgüven, A. (2001). “iktisadi Krizler”, Yeni Türkiye Ekonomik Kriz Özel Sayısı I, Sayı 41, YIl 7, ss.56-63. 
Özsoylu, A. F., Ünlükapan, İ. \& Gedik, M. A. (2010). Küresel Kriz ve Türkiye, Adana, Karahan Kitapevi.

Ramadhan, M. \& Naseeb A. (2015). "The Global Financal Crisis: Causesand Solitions", http://www.wbiconpro.com/323-Adeel-new.pdf (Erişim 30.04.2015).

Selen, U. (2009). "Konjonktürel Dalgalanmalarda Maliye Politikasının Rolü ve Kriz Yönetimi”, Güncel Mali Konular, (Ed.) Edizdoğan N., Bursa, Dora Yayıncılık, ss.239268.

Tarı, R., Eraslan, C. \& Bayraktar Y. (2011). “Küresel Ekonomik Kriz ve Belirleyicileri Üzerine Bir Değerlendirme", Küresel Ekonomik Kriz ve Finansal Kriz Türkiye Ekseninde Sorunlar ve Çözüm Önerileri, (Ed.) Çetinkaya M., Ankara, Nobel Yayıncılık, ss.7-26.

T.C. Başbakanlık Hazine Müsteşarlığı. (2009). Soru Önergesine Illişkin Olarak Hazine Müsteşarlığı Tarafından Hazırlanmış Cevap Metni, http://www2.tbmm.gov.tr/ d23/7/7-8872c.pdf ( E.T.07.06.2015).

Tepav. (2009). 2007-08 Küresel Finans Krizi ve Türkiye: Etkiler ve Öneriler, Politika Notu.

Turhan, S. (1998). Vergi Teorisi ve Politikası, İstanbul, Filiz Kitapevi.

Turhan S. (2002). "iktisadi İstikrar ve Vergi Politikası Uygulamasına iliş̧kin Sorunlar", Istanbul Ticaret Üniversitesi Dergisi, C.1, S.1, ss.59-86.

Wasserstom, E. (2008). "On the Financial Crisis: It's Not Just Weak Oversight", The New York Times, 17 September 2008, http://campaignstops.blogs.nytimes.com/ 2008/09/17/on-the-financial-crisis-its-not-just-weak-oversight/?_r=0 (04.05.2015).

Yay, G. G. (2012). Para ve Finans, İstanbul, Bilgi Üniversitesi Yayınları.

2009/14802 Sayılı Bakanlar Kurulu Kararı, http://www.resmigazete.gov.tr/ eskiler/2009/03/20090316-7.htm (E.T. 09.06.2015).

2009/14812 Sayılı Bakanlar Kurulu Kararı, http://www.resmigazete.gov.tr/eskiler/ 2009/03/20090329-4.htm (E.T. 09.06.2015).

2009/15081 Sayılı Bakanlar Kurulu Kararı, http://www.resmigazete.gov.tr/eskiler/ 2009/06/20090616M1- 1.htm (E.T. 09.06.2015). 